\author{
Hortensia Pârlog* \\ University of Timisoara \\ Faculty of Letters, History and Theology \\ Department of English Language and Literature \\ Timisoara, Romania
}

\title{
PROGRESSIVE ASPECT TODAY: THE STATIVE VERBS
}

I'm Wishing I'm wishing for the one I love To find me today.

(From "Snow White and the seven dwarfs" Music and Lyrics by Frank Churchill and Larry Morey)

\begin{abstract}
Linguists have been aware of the imperfections of the semantic division of verbs into dynamic and stative, which has been used in teaching grammatical aspect. Stative verbs are frequently used in the progressive aspect nowadays, so one wonders about the necessity of this classification, since it does not reflect actual usage. A verb is not inherently stative or dynamic; it is often stative or often dynamic depending on the lexical and grammatical context in which it appears. The paper discusses some of the stative verbs and gives the results of a survey on the degree of acceptance of "unusual" progressive uses of such verbs by three different age groups of educated native speakers of English.
\end{abstract}

Key words: progressive aspect, stative verbs, language use, meaning, context

E-mail address for correspondence: abaparlog@gmail.com 


\section{Introduction}

The opposition between progressive and non-progressive tense forms in English was aptly characterized forty years ago by Leech (1969:148) as "notoriously problematic, and a major difficulty for foreign learners of English".

The progressive aspect marks actions and states that are in progress at a given, limited period of time (present, past or future). The use of the progressive aspect is traditionally discussed by taking into account the semantics of the verbs; all books of grammar (e.g., Leech 1971, Quirk et al. 1972, 1985, Comrie 1981, etc.) provide examples of verbs considered stative, that "are normally incompatible with the progressive" (Leech 1971: 19), that "cannot normally occur with the progressive aspect" (Quirk et al. 1985: 204), for which progressive "is generally excluded" (Leech 1971: 23). The hedging used in their definition points to the fact that linguists have been aware of the imperfections of the semantic division of verbs into dynamic and stative.

The classes of stative verbs that grammars discuss are the following:

1. Verbs denoting mental states and processes (or verbs of cognition): e.g., agree, believe, differ, disagree, disbelieve, distrust, feel (= "be of the opinion"), find, foresee, forget, imagine, know, mean, realize, recall, recognize, recollect, remember, suppose, think (= "believe"), trust, understand;

2. Verbs denoting emotions or attitudes: e.g, adore, abhore, astonish, desire, detest, dislike, displease, forgive, hate, hope, like, love, mind (= "object to"), please, prefer, want, wish;

3. Verbs denoting perception: e. g., behold, feel, hear, notice, observe, see, smell, taste, recognize, watch;

4. Relational verbs: e.g., apply (to sb.), appear (= "seem"), be, belong, concern, consist, contain, comprise, cost, depend, deserve, equal, find, fit, have, include, involve, lack, matter, need, owe, own, possess, remain, require, resemble, result, seem, sound, etc.

All grammars discuss cases when these verbs can, however, be used in the progressive. Learners of English are told that this happens

$\triangle$ when verbs suffer a change of meaning, e.g.

(1) Who is seeing to ['taking care of'] the arrangements?

(2) He is always differing ['quarrelling'] with his father. 
$\triangleright$ when they denote an action taking place gradually, slowly, by degrees, e.g.

(3) I'm not hearing as well as I used to.

(4) He is finding that English is rather difficult.

$\triangleright$ when they denote a voluntary, deliberate action, a conscious effort of perception, e.g.

(5) I'm tasting the cake to see whether it is sweet enough.

(6) He was feeling my arm to see whether it was broken.

$\triangleright$ or when they refer to a repeated action, e.g.

(7) He is constantly doubting my word.

(8) What's she wanting this time, I wonder?

The number of exceptions seems, however, to be much higher nowadays, so high in fact, that Romanian learners of English, in whose native language grammatical aspect is poorly represented, wonder about the necessity of this verb classification into stative and dynamic for their study of the progressive aspect, since it does not reflect actual usage. In the Romanian grammar, an action in progress can be suggested only for the past time, by the tense called imperfect, which can be used with all verbs, e.g.

(9) Când m-ai sunat, mă gândeam la tine.

When me-have called, me thought at you.

'When you called, I was thinking of you.'

A brief search on the Internet and a questionnaire were used in order to gather information on the use of stative verbs in the progressive aspect by native speakers of English; their results are given in what follows.

\section{The Internet search}

The use in the progressive aspect of the following thirty three verbs has been checked by carrying out a Google search on the Internet. The choice of verbs was random; they were grouped afterwards, according to grammar prescription, as follows: 
a) mental states and processes: agree, believe, differ, doubt, feel, find, foresee, forget, guess, imagine, intend, know, mean, mind, realize, recall, recognize, recollect, remember (19);

b) emotional states: adore, desire, detest, dislike, forgive, hate, impress, want (8);

c) perception: hear, see (2);

d) relational verbs: appear, contain, seem, weigh (4).

Dictionaries like Oxford Advanced Learner's Dictionary, by A. S. Hornby, fifth edition, Jonathan Crowther (ed.), OUP, 1995 or Macmillan English Dictionary for Advanced Learners, 2002, give information about the use of these verbs which does not always coincide. Thus, in Hornby, the following twelve verbs in my list are marked as "not used in the continuous tenses": adore, believe, contain, desire, detest, forget, recognize, recollect, realize, remember, see, seem. In Macmillan, a distinction is made between "never progressive" (adore, hear, see, seem, know) and "not usually progressive" (agree, believe, recognize) (a total of eight verbs). One can notice that it is only for five verbs (adore, believe, recognize, see, seem) that the two dictionaries give approximately similar information.

\subsection{The thirty three stative verbs in the present, past and future progressive}

The results of my Internet check on the use of the thirty three verbs in the present, past and future progressive can be seen in Appendix I. Most of these results are corroborated by the data stored in the British National Corpus (BNC), whose latest edition, the third, was released in 2007. Its written part, "(90\%), includes ... extracts from regional and national newspapers, specialist periodicals and journals for all ages and interests, academic books and popular fiction, published and unpublished letters and memoranda, school and university essays, among many other kinds of text" (http://www.natcorp.ox.ac.uk/corpus/index.xml).

Only two of the verbs (of the 33) are never encountered in any of the tenses of progressive: differ and feel (the latter in the sense of 'to be of the opinion'). The BNC search, however, provides several examples for the verb feel with this meaning as well: 
(10) The majority of women (...) are feeling that they must start protecting family life. (http://bnc.bl.uk/)

(11) I am feeling that I must hold back. (http://bnc.bl.uk/)

The most resistant to the use of these verbs in the progressive is the future tense: 16 of the 33 verbs have never been found to occur in this tense and another 4 appear only rarely in the future progressive (believe, foresee, forget, mind):

(12) If they believe something today, there is no general guarantee that they will be believing it tomorrow. (books.google.com/)

(13) All races (Nations Cup and Sicily Grand Prix) will be scored for the whole event and different Rankings will be foreseeing as follows...

(www.albaria.it/wwf/wwf97/501.htm)

(14) they (...) help people forget their daily worries. Thus, half of British (55\%), French (51\%) and Spanish (51\%) adults will be forgetting, while...

(graphics8.nytimes.com/packages/pdf/world/.../20090626iht-poll.pdf)

(15) I can actually see our profitability increasing [...] and I don't think the MD will be minding that at all (books.google.com/).

In BNC, a single sentence illustrates the use of the verb to believe in the future progressive, while the other three verbs do not appear in this tense at all.

Six verbs never occur in the past progressive (differ, feel, mind, recall, adore, appear) and four in the present progressive (differ, feel, mind, mean,), while in each of these two tenses, two verbs are rarely used (imagine, appear - in the present, imagine, believe - in the past):

(16) I am imagining that it is raining outside and very cold... (explore.twitter.com/ben_alfac/status/1893897975 -)

(17) Is it a cultural difference, or was I imagining that he was attracted to me?

(www.dearcupid.org/...)

(18) This whole tragedy is appearing very suspect as some type of cover up...

(www.democraticunderground.com/...) 
(19) i just didnt like how he was believing you when it wasn't even true

(profile.myspace.com/index.cfm?fuseaction)

The BNC contains no examples for differ, feel, and adore, while mind occurs in the progressive only with the meaning 'to take care of', 'look after'; there is no illustration for imagine in the past, and only one example for imagine in the present, and for believe in the past; on the other hand, there are thirteen examples for was recalling, two for were recalling, and thirty four for are appearing (against one only for the first person singular, am appearing, where the verb has the meaning 'to go to a court of law'):

(20) He told me (and I believe him) that he was recalling the dry cadences of a famous essay by the great economist. (http:// bnc.bl.uk/)

(21) It is difficult to improve further, younger rivals are appearing, contemporaries in other fields are in settled careers. (http:// bnc.bl.uk/)

Several interesting uses must be commented upon; they concern the (non)association of some of these verbs with a certain grammatical person, a certain sentence type, or a certain tense form.

Thus, recall in the present progressive and mean in the past progressive were found to occur only in the first person:

(22) there is an internal sensation of 'I am recalling something'. (books.google.com)

(23) I accidentally marked an e-mail as junk when I was meaning to mark it as safe (windowslivehelp.com/community/t/60377. aspx-).

If used with other persons of the present progressive than the first, recall has a different meaning ( = 'to withdraw from the market'):

(24) Toyota is recalling 436000 hybrid cars worldwide (news.bbc.co.uk/2/hi/8505402.stm) 
(25) records of information that will help other businesses and the public to identify and return the food you are recalling (www. foodstandards.gov.au/)

On the other hand, find in the past progressive never occurs in the first person singular:

(26) Researchers were finding flaws in the new browser's coding within an hour of its release (www.informationweek.com/)

BNC, however, has three examples for recall in other persons than the first, with no change of meaning, and eight examples for find in the first person:

(27) the narrator is recalling his father's days as a medium and healer

(http://bnc.bl.uk/)

(28) The area suggested that there could be earlier finds but I was not too disappointed with what I was finding. (http://bnc. bl.uk/)

In the present progressive, forget is most frequent in questions, but BNC offers only texts in which this form occurs in declarative sentences:

(29) Banks are forgetting lessons of crisis already, warns Turner (wallstreetblips.dailyradar.com)

My search on the Internet has yielded no results for want in the present progressive; I have only come across messages with the verb in the present perfect progressive:

(30) I've been wanting a pair of TOMS shoes for a long while now. (www.ecosalon.com/)

BNC, however, has thirty two sentences in which want is employed in the present progressive as well:

(31) What else is it that you are wanting to do? (http://bnc.bl.uk/) 
(32) The companies are wanting to recover development costs. (http://bnc.bl.uk/)

\subsection{Complementation}

The preferred type of complementation taken by the stative verbs analysed is the monotransitive one: twenty five stative verbs used in the progressive aspect are frequently followed by a Noun Phrase, and, of these, fifteen also take a finite clause object in the surface structure (a THAT or a WHclause); fourteen of the verbs take no complementation, being intransitive or being used intransitively (see Appendix II). For example:

$D+\mathrm{NP}$

(33) I am agreeing a compromise agreement to leave employment. (www.justanswer.com)

(34) if they believe something today there is no general guarantee that they will be believing it tomorrow. (books.google.com/)

(35) Thus by knowing them, He is knowing Himself. There is no separation whatsoever. (www.chabad.org/library/...)

(36) Banks are forgetting lessons of crisis already, warns Turner (wallstreetblips.dailyradar.com/)

$D+$ clause

(37) I am recognizing that the voice inside my head is urging me to be myself and never follow someone else... (www.plurk.com)

(38) I am finding that being better dressed than the rest of the team (amongst females) creates mixed feelings. (talentegg.ca/ incubator)

(39) I am hearing ... I am hearing what you are saying (www.english-test.net/forum/ftopic1066.html -)

(40) It was clear that the surgeon was seeing what he or she believed.

(www.ctlab.org/documents)

$\triangle$ Intransitive use

(41) When I am doubting, I cannot doubt that I am doubting. (books.google.com/) 
(42) If I am recalling correctly, Andrew Wyeth was found to have a mistress.

(message.snopes.com)

(43) The first is for people who aren't remembering well enough. The second is for people who are remembering too well. (www.ucop. edu/sciencetoday/)

(44) When you were hearing, did you know any deaf or hard of hearing people? (deafness.about.com)

\section{The questionnaire}

A questionnaire made up of 22 sentences was administered to 24 educated native speakers of American English, who were asked to judge their grammatical correctness. Ten of the sentences had predicates expressed by stative verbs in the progressive aspect; the other sentences were not all correct (see Appendix III); the sentences were "authentic" (i.e. taken from the Internet or very slightly adapted).

The twenty four respondents were divided into three groups: they were nine students aged $18-24$, ten persons aged $30-50$, and five aged 51 - 70. Nine of them, of whom three teachers of English, had a PhD.

The results of the survey are expressed in percentages in the tables below.

Table 1. Overall results (24 subjects)

\begin{tabular}{|l|l|l|}
\hline Verbs & $\begin{array}{l}\text { OK in the } \\
\text { progressive }\end{array}$ & Not OK \\
\hline Hear & $22-\mathbf{9 1 . 7} \%$ & $2-8.3 \%$ \\
\hline Remember & $18-\mathbf{7 5} \%$ & $6-25 \%$ \\
\hline Seem & $17-\mathbf{7 0 . 9} \%$ & $7-29.1 \%$ \\
\hline Adore & $17-\mathbf{7 0 . 9} \%$ & $7-29.1 \%$ \\
\hline Intend & $16-\mathbf{6 6 . 7} \%$ & $8-33.3 \%$ \\
\hline Doubt & $14-\mathbf{5 8 . 3} \%$ & $10-41.7 \%$ \\
\hline Foresee & $13-\mathbf{5 4 . 2} \%$ & $11-45.8 \%$ \\
\hline Believe & $13-\mathbf{5 4 . 2} \%$ & $11-45.8 \%$ \\
\hline Detest & $8-33.3 \%$ & $16-66.7 \%$ \\
\hline Know & $5-20.9 \%$ & $19-79.1 \%$ \\
\hline
\end{tabular}


Table 2. Results calculated for each of the three groups

\begin{tabular}{|l|l|l|l|}
\hline & Age 18 - 24 (9) & Age 30 - 50 (10) & Age 51 - 70 (5) \\
\hline & Not OK & Not OK & Not OK \\
\hline Hear & - & - & $2-40 \%$ \\
\hline Remember & $1-11.1 \%$ & $4-40 \%$ & $1-20 \%$ \\
\hline Seem & $1-11.1 \%$ & $5-50 \%$ & $1-20 \%$ \\
\hline Adore & - & $5-50 \%$ & $2-40 \%$ \\
\hline Intend & $1-11.1 \%$ & $4-40 \%$ & $3-60 \%$ \\
\hline Doubt & - & $6-60 \%$ & $4-80 \%$ \\
\hline Foresee & $2-22.2 \%$ & $6-60 \%$ & $3-60 \%$ \\
\hline Believe & - & $9-\mathbf{9 0} \%$ & $4-\mathbf{8 0} \%$ \\
\hline Detest & $2-22.2 \%$ & $9-\mathbf{9 0} \%$ & $5-100 \%$ \\
\hline Know & $6-\mathbf{6 6 . 6} \%$ & $10-\mathbf{1 0 0} \%$ & $3-\mathbf{6 0} \%$ \\
\hline
\end{tabular}

The results expressed in percentages show that native speakers of English do not seem to agree among themselves as to the (in)correctness of the progressive use of a certain verb. Of the three groups of informants, the students (aged 18-24) were more lenient in their judgement of grammatical correctness; they objected mainly to the use in the progressive of the verb know and only occasionally to some of the other verbs. The respondents in the other two groups were less tolerant of the mistakes, but, except for their reaction to the verbs know and detest, they were not one hundred per cent against the use of all the stative verbs in the progressive.

The progressive forms of the verbs most objected to were, besides know and detest (judged by more than half of the respondents as incorrect), believe, foresee (11 each), doubt (10), intend (8) and adore (7). Seven of the progressive verb forms were considered correct by more than half of the respondents, which means that those verbs are no longer regarded as stative. The use of hear, remember, seem and adore in the progressive is $\underline{\mathrm{ok}}$ for a large majority of the respondents (more than 70 percent; the verb hear in the progressive was accepted by 22 respondents).

The three teachers of English were the only ones to also make some unsolicited written comments on several of the sentences, which I would like to mention here, because they might make one wonder about their acceptability in class: 
$\rightarrow$ "OK or NOT OK, depending on what "at the moment" is intended to modify." (sentence 18, We're hearing a lot about war crimes at the moment);

$\rightarrow$ "This would be a vivid present progressive."(??) (sentence 14, One moment I am adoring you, and the next I am shaking my fist at you);

$\rightarrow$ "Here the progressive tense can work, depending on the writer's meaning." (sentence 21, For many, the American dream is seeming more like just a dream);

$\rightarrow$ "This is a bit awkward" (idem);

$\rightarrow$ It is "a bit more conversational in tone than the simple present" (idem);

$\rightarrow$ "The progressive doesn't work well here." (several of the sentences).

\section{Conclusion}

Both Leech (1971:19) and Quirk et al. (1985:202, Note) admit that meaning is not the only factor that explains the constraints of the progressive. Both discuss the relational verb resemble, which, they say, may admit the progressive if accompanied by a word in the comparative degree. This is not confirmed by the data collected from the Internet messages or the BNC, where not one example of such use was found. However, examples containing the comparative degree were found for the relational verbs cost and matter:

(45) Basic needs of families in state are costing more (seattletimes.nwsource.com/html)

(46) But in 1985 it was mattering less whether it was true or not (books.google.com)

(47) ... at each assessment period, Newham Services were costing more.

(http://bnc.bl.uk/).

Leech (1971: 26) also points out that the verb hear, even if referring to a process of communication (i.e. 'to receive a message'), cannot be used in its past progressive form in questions ("*)Were you hearing about that terrible accident?"). Still, one can find two examples in the BNC: 
(48) Was she hearing, in the gentle wind, eddying along the purpling coastline, the ghost lamentations of the thousands of sgitheanachs that had ended up against their will in her country over the Big Water? (http://bnc.bl.uk/)

(49) Was she hearing things? (http://bnc.bl.uk/)

Native speakers may be inconsistent in their use of stative verbs in the progressive aspect, but it is clear that the forms stigmatized a few years ago are now judged as acceptable by native language users, and that the number of dynamic uses of stative verbs is obviously on the increase. Mair (2006) states that " 'stative' progressives are ... not the recent innovation they are considered to be by many commentators" (2006: 94), demonstrating with well chosen examples from Evelyn Waugh, George Eliot, Jane Austin, that the phenomenon is not new, and regarding it "as an instance of contextually/pragmatically licensed rule-breaking for specific rhetorical or expressive effect." (2006: 92). Still he admits that the reasons for this change are difficult to explain (cf. Mair 2006: 88).

I am aware that my study cannot claim to be rigorous, but it is meant to draw, once more, the attention to an area where some changes in the grammar taught to learners of English as foreign language must take place. 'Deviant' uses as those presented leave the foreign learners very insecure about the validity of the normative rules which they have to learn, and which are taken into account in their evaluation in class or when they sit for the very conservative Cambridge or TOEFL exams.

There is an obvious gap between these rules and actual language use; one must become aware that a verb is not inherently stative or dynamic; it is often stative or often dynamic, depending on the lexical and/ or grammatical context in which it appears, or on the speaker's/writer's meaning. That means one cannot have some systematic rules to learn and apply automatically. 


\section{References}

Comrie, B. (1981). Aspect. An Introduction to the Study of Verbal Aspect and Related Problems. Cambridge: Cambridge University Press.

Leech, G. (1969). Towards a Semantic Description of English. London: Longmans.

Leech, G. (1971). Meaning and the English Verb. London: Longman. Mair, C. (2006). Twentieth Century English. History, Variation, Standardization. Cambridge, New York etc.: Cambridge University Press.

Quirk, R., S. Greenbaum, G. Leech, J. Svartvik. (1972). A Grammar of Contemporary English. London: Longman.

Quirk, R., S. Greenbaum, G. Leech, J. Svartvik. (1985). A Comprehensive Grammar of the English Language. Harlow: Longman.

\section{Appendix I}

Stative verbs in the present, past and future progressive

\begin{tabular}{|l|l|l|l|}
\hline Verb & Present & Past & Future \\
\hline agree & + & + & + \\
\hline believe & + & few & few \\
\hline differ & no & no & no \\
\hline doubt & + & + & no \\
\hline $\begin{array}{l}\text { feel ('be of the opinion; } \\
\text { have an opinion') }\end{array}$ & no & no & no \\
\hline find & + & + no 1st & no \\
\hline foresee & + & + & person sg. \\
\hline forget & + frequent in & + & very few \\
\hline guess ('suppose') & + & + & no \\
\hline $\begin{array}{l}\text { imagine ('suppose, } \\
\text { believe') }\end{array}$ & very few & very few & no \\
\hline intend & + & + & + \\
\hline know & + & + & + \\
\hline mean & no & only 1st person & no \\
\hline mind ('object to') & no & no & very rare \\
\hline realize & + & + & + \\
\hline
\end{tabular}




\begin{tabular}{|l|l|l|l|}
\hline recall (remember) & $\begin{array}{l}+ \text { usually } 1^{\text {st }} \\
\text { person }\end{array}$ & no & no \\
\hline recognize & + & + & + \\
\hline recollect & + & + & no \\
\hline remember & + & + & no \\
\hline adore & + & no & no \\
\hline desire & + & + & + \\
\hline detest & + & + & + \\
\hline dislike & + & + & no \\
\hline forgive & + & + & + \\
\hline hate & + & + & + \\
\hline impress & + & + & + \\
\hline want & + (present & + & + \\
\hline hear & perfect only) & & no \\
\hline see & + & + & + \\
\hline appear & + & + & no \\
\hline contain & very few & no & + \\
\hline seem & + & + & no \\
\hline weigh ('have weight') & + & + & no \\
\hline
\end{tabular}

\section{Appendix II}

Complementation

\begin{tabular}{|l|l|l|l|}
\hline Verb & intransitive & \multicolumn{1}{|c|}{ + NP } & + clause \\
\hline agree & + & + & \\
\hline believe & & + & + \\
\hline differ & & & \\
\hline doubt & + & + & + \\
\hline feel & & & \\
\hline find & & + & + \\
\hline foresee & & + & + \\
\hline forget & + & + & + \\
\hline guess & & & + \\
\hline imagine & & & + \\
\hline intend & & & \\
\hline know & & + & + \\
\hline
\end{tabular}




\begin{tabular}{|c|c|c|c|}
\hline mean & & + & + \\
\hline mind & & + & \\
\hline realize & + & + & + \\
\hline recall & + & + & + \\
\hline recognize & & + & + \\
\hline recollect & + & + & + \\
\hline remember & + & + & + \\
\hline adore & & + & \\
\hline desire & & + & \\
\hline detest & + & + & \\
\hline dislike & & + & \\
\hline forgive & & + & \\
\hline hate & + & + & \\
\hline impress & & + & \\
\hline want & & + & \\
\hline hear & + & + & \\
\hline see & + & + & + \\
\hline appear & + & & \\
\hline contain & & + & \\
\hline seem & + & & \\
\hline weigh & + & & \\
\hline
\end{tabular}

Appendix III

Questionnaire

OK Not OK

$=\mathrm{=}=\mathrm{=}=\mathrm{=}=\mathrm{=}=\mathrm{=}=\mathrm{=}=\mathrm{=}=\mathrm{=}=\mathrm{=}=\mathrm{=}=\mathrm{=}=\mathrm{=}=\mathrm{=}=\mathrm{=}$

1. Help me solve this.

2. I am believing you guys will get through this.

3. He didn't think this would happen again.

4. They wish I just wasn't there.

5. So she was doubting the AF447 crash was due to weather.

6. Did you talk to her yet?

7. I am foreseeing a further collapse in credit cards.

8. I wish I had a job as you've got.

9. Here is a list of films I am intending to see this year.

10. They are knowing deep down in themselves they are not fully prepared for it.

11. If you promise to do it, I would believe you.

12. Your presentation started from a description, isn't it? 
13. I think you guys are remembering incorrectly.

14. One moment I am adoring you, and the next I am shaking my fist at you.

15. Hardly did we stop talking when a knock was heard on the door.

16. His best friend was detesting him, which was sad.

17. How do you dare to say that?

18. We're hearing a lot about war crimes at the moment.

19 . Did you use to go there by yourself?

20. I am going to be 30 next month.

21. For many, the American dream is seeming more like, well, just a dream.

22. She told me he invited her the previous week.

Received: 12 June, 2011

Accepted for publication: 1 October, 2011

\section{Хортензија Парлог}

ПРОГРЕСИВНИ АСПЕКТ ДАНАС: СТАТИВНИ ГЛАГОЛИ

\section{Сажетак}

Лингвисти су свесни несавршености семантичке поделе глагола на динамичке и стативне, која се користи у настави граматичког аспекта глагола. Стативни глаголи данас се често употребљавају у прогресивном аспекту, тако да се поставља питање потребе за оваквом класификацијом, будући да она не одражава стварну употребу језика. Глагол није инхерентно стативан или динамички; он је често стативан или често динамички у зависности од лексичког и граматичког контекста у коме се јавља. У раду се разматрају одређени стативни глаголи и представљају се резултати испитивања степена прихватљивости „неуобичајених“ употреба тих глагола у прогресивном аспекту код три различите старосне групе образованих изворних говорника енглеског језика.

Кључне речи: прогресивни аспект, стативни глаголи, језичка употреба, значење, контекст 